\title{
STUDI KINERJA PT BNI SYARIAH SESUDAH PEMISAHAN (SPIN OFF) DARI PT BANK BNI (PERSERO) TBK.
}

\author{
Achmad Chotib \\ Wiwik Utami \\ Universitas Mercu Buana
}

\begin{abstract}
The purpose of this study was to analyze the performance of BNI Syariah before the spin-off compared with after the spin-off and to analyze the performance of BNI Syariah after the spin-off compared with the performance of BJB Syariah after the spin off. Both of the performance analysis based on CAR, NPF, NPM, ROA, ROE, and FDR. The study was conducted by using analysis Paired Sample T-Test and analysis Independent Sample T-Test. The results showed that the performance of BNI Syariah before and after the spin-off does not difference significantly. Likewise for the comparation of BNI Syariah and BJB Syariah after spin off, some ratios (NPF, NPM, ROA, ROE) did not differ significantly with probability greater than 0.05 , and for CAR and FDR, there was a significant difference with probability lower than 5 percen.
\end{abstract}

Keyword: Sharia Bank, Spin Off, Performance, Financial Ratios.

ABSTRAK: Tujuan dari penelitian ini adalah untuk menganalisis kinerja BNI Syariah sebelum spin-off dibandingkan dengan setelah spin-off dan untuk menganalisis kinerja BNI Syariah setelah spin-off dibandingkan dengan kinerja BJB Syariah setelah spin off. Kedua analisis kinerja berdasarkan CAR, NPF, NPM, ROA, ROE, dan FDR. Penelitian dilakukan dengan menggunakan analisis Paired Sample T-Test dan analisis Independent Sample TTest. Hasil penelitian menunjukkan bahwa kinerja BNI Syariah sebelum dan sesudah spinoff tidak perbedaan signifikan. Demikian juga untuk perbandingan dari BNI Syariah dan BJB Syariah setelah spin off, beberapa rasio (NPF, NPM, ROA, ROE) tidak berbeda secara signifikan dengan probabilitas lebih besar dari o,05, dan untuk CAR dan FDR, ada perbedaan yang signifikan dengan probabilitas rendah dari 5 percen.

Kata kunci : Bank Syariah, (pemisahan) Spin Off, Kinerja, Rasio Keuangan.

\footnotetext{
Draft pertama: 21 Maret 2014 Revisi: 15 April 2014 Diterima: 20 Mei 2014
}

*Penulis dapat dikontak melalui: achmad.chotib@bnisyariah.co.id 


\section{PENDAHULUAN}

Bank memiliki peranan sangat penting bagi upaya pemerintah dalam meningkatkan kesejahteraan ekonomi dan status sosial masyarakat. Tak dapat dibayangkan, bagaimana suatu negara dapat membangun perekonomian tanpa keterlibatan bank dalam kegiatan ekonomi dan sosialnya, dan bank syariah dapat dijadikan sebagai alternatif dalam kegiatan tersebut. Bank syariah pertama di Indonesia adalah PT Bank Muamalat Indonesia, Tbk. (BMI) merupakan yang mulai beroperasi 1 Mei 1992. Krisis moneter tahun 1998 memberikan dampak bagi BMI yaitu Non-Performing Financing (NPF) mencapai lebih dari 6o\%, sehingga BMI mengalami kerugian sebesar Rp 105 miliar dengan jumlah ekuitas mencapai titik terendah yaitu kurang dari sepertiga modal awal yang disetor. BMI kemudian bekerjasama dengan Islamic Development Bank (IDB) dan membalikkan keadaan dari kondisi rugi menjadi laba.

Dalam perkembangannya, bank syariah tidak hanya diminati oleh umat Islam melainkan juga oleh umat non Islam, sehingga beberapa bank konvensional baik nasional maupun internasional banyak yang mendirikan Bank Umum Syariah (BUS) yang berasal dari pendirian BUS baru, konversi dari bank, spin off dan konversi spin off. Hanya ada 2 bank yang betul-betul spin off yaitu PT. Bank BNI Syariah (BNI Syariah) dan PT. Bank Jabar \& Banten Syariah (BJB Syariah).

Berdasarkan data Bank Indonesia, perbankan syariah tumbuh sekitar 15-18,7\% pada 2006-2010. Per 2010 sendiri, pertumbuhan aset perbankan syariah adalah 47,6\%, jauh di atas perbankan nasional yang hanya 3,2\%. Volume usaha perbankan syariah dalam kurun waktu tahun 2011 mengalami pertumbuhan yang sangat signifikan. Total Aset per-Oktober 2011 (yoy) telah mencapai Rp. 127,19 triliun atau meningkat tajam sebesar 48,10\% yang merupakan pertumbuhan tertinggi sepanjang 3 tahun terakhir. Ditambah dengan aset BPRS sebesar Rp. 3,35 triliun, total aset perbankan syariah per-Oktober 2011 telah mencapai Rp. 130,5 triliun. Market-share perbankan syariah terhadap perbankan nasional telah mencapai sekitar 3,8\%. Sedangkan jumlah kantor bank syariah pada Oktober 2012 adalah 2.574 kantor.

Pada akhir 2011, industri perbankan syariah Indonesia dikejutkan oleh Global Islamic Finance Report (GIFR) 2011 yang dikeluarkan oleh BMB Islamic, konsultan keuangan syariah berbasis di London. Kejutannya adalah, Indonesia menduduki peringkat keempat dalam Islamic Finance Country Index (IFCI) setelah Iran, Malaysia, dan Arab Saudi. Melihat hal tersebut, banyak fenomena bisnis keuangan syariah yang menarik untuk dicermati, baik untuk keperluan evaluasi, forecasting, maupun pemetaan. Tak terkecuali dengan kinerja BNI Syariah yang melakukan spin off dari PT BNI (Persero) Tbk. pada tanggal 19 Juni 2010. Sebelum melakukan spin off menjadi BUS, BNI Syariah telah membukukan aset per 31 Maret 2010 senilai Rp.5,49 triliun. Sementara, total Dana Pihak Ketiga (DPK) adalah sebesar Rp.4,2 triliun dan total pembiayaan sebesar Rp.3,2 triliun dengan customer based lebih dari 420 ribu nasabah. Setelah melakukan spin off, BNI Syariah mencatat aset per 31 Maret 2012 sebesar Rp. 9,22 triliun, total Dana Pihak Ketiga (DPK) adalah sebesar Rp.6,9 triliun, dan total pembiayaan sebesar Rp.7,9 triliun dengan customer based lebih dari 715 ribu nasabah.

Sedangkan BJB Syariah yang melakukan spin off dari PT Bank Jabar (Persero) Tbk pada bulan Mei 2010, memiliki jaringan kantor sebanyak 21 kantor yang terdiri dari 6 kantor cabang dan 15 kantor cabang pembantu yang tersebar di wilayah Jawa Barat dan Banten. BJB Syariah pada triwulan I 2011 telah membukukan aset Rp1,8 triliun, pembiayaan Rp1,59 triliun, penghimpunan DPK Rpı,14 triliun serta laba senilai Rp 4,23 miliar.

Kinerja menurut Hidayah (2007) adalah suatu penilaian atas prestasi dan kondisi keuangan pada suatu perusahaan pada periode tertentu dan membutuhkan ukuran-ukuran tertentu, dan biasanya yang digunakan dalam menganalisis rasio untuk menunjukkan antara dua data keuangan. Penggunaan rasio keuangan sampai saat ini masih digunakan karena merupakan cara yang paling umum dan mudah, sehingga banyak digunakan dalam pengukuran kinerja suatu bank. Begitu pula halnya bank syariah di Indonesia, sampai saat 
ini analisa rasio keuangan bank syariah masih menggunakan aturan yang berlaku di bank konvensional.

Sesuai Undang-Undang No. 21 tahun 2008 tentang Perbankan Syariah dan Cetak Biru Pengembangan Perbankan Syariah Indonesia, Bank Indonesia mengeluarkan Peraturan Bank Indonesia (PBI) No. 9/1/PBI/2007 tentang Sistem Penilaian Kesehatan Bank Umum Berlandaskan Prinsip Syariah. Berdasarkan BPI tersebut, tingkat kesehatan bank diukur dengan menggunakan 5 (lima) aspek, yaitu: Capital, Assets Quality, Management, Earning, dan Liquidity atau lebih dikenal dengan sebutan CAMEL.

Penelitian yang dilakukan Cristianti (2008) tentang analisis kinerja bank sebelum dan sesudah program rekapitalisasi, mengukur kinerja perbankan menggunakan rasio-rasio CAMEL. Rasio CAMEL yang digunakan CAR, RORA, NPM, ROA, rasio BOPO, rasio kewajiban bersih call money terhadap aktiva lancar, rasio kredit terhadap dana yang diterima. Pengujian dilakukan menggunakan Uji Beda Wilcoxon yang menghasilkan kesimpulan adanya perbedaan kinerja bank yang signifikan untuk tahun-tahun sebelum dan sesudah program rekapitalisasi. Meskipun beberapa diantara rasio CAMEL (RORA, ROA dan BOPO) memberi indikasi tidak ada perbedaan kinerja yang signifikan untuk tahun-tahun sebelum dan sesudah program rekapitalisasi.

Tujuan Penelitian ini adalah untuk menganalisis Kinerja BNI Syariah sesudah Spin Off berdasarkan rasio keuangannya yaitu dengan: mengkaji kinerja BNI Syariah sebelum spin off dibandingkan sesudah spin off berdasarkan CAR, NPF, NPM, ROA, ROE, dan FDR; dan mengkaji kinerja BNI Syariah sesudah spin off dibandingkan dengan kinerja BJB Syariah sesudah spin off berdasarkan CAR, NPF, NPM, ROA, ROE, dan FDR.

\section{KERANGKA TEORI DAN PENGEMBANGAN HIPOTESIS Kombinasi Bisnis}

Menurut Beams, Brozovsky \& Beams (2008) kombinasi bisnis adalah penyatuan entitas bisnis yang sebelumnya terpisah menjadi satu entitas melalui akuisisi asset bersih atau saham suara terbesar sebuah perusahaan oleh perusahaan lain atau melalui perdagangan saham. Meskipun tujuan utama kombinasi bisnis adalah keuntungan, namun kebanyakan sasaran utamanya adalah mencapai efisiensi operasional melalui integrasi operasional secara vertikal atau horizontal ataupun membagi risiko bisnis melalui operasi konglomerasi.

Integrasi horizontal adalah kombinasi antar perusahaan yang memiliki jenis dan pasar yang sama, contoh PT Bank BNI (Persero)Tbk dengan PT Bank BNI Syariah. Sedangkan integrasi vertikal adalah kombinasi bisnis perusahaan dengan jenis yang berbeda tetapi mempunyai tingkat produksi dan atau distribusi yang sama dan berhubungan.

Kombinasi bisnis merupakan bentuk umum penggabungan yang meliputi seluruh bentuk entitas bisnis yang sebelumnya terpisah. Adapun bentuk kombinasi bisnis adalah:

\section{Merger}

Merger adalah penggabungan dua atau lebih perusahaan yang kemudian hanya ada satu perusahaan yang tetap hidup sebagai badan hokum, sementara yang lainnya menghentikan aktifitasnya atau bubar (Abdul Moin 2003;5). Sedangkan menurut Peraturan Pemerintah Republik Indonesia No. 27 tahun 1998 tentang penggabungan, Peleburan dan Pengambilalihan Perseroan Terbatas, merger adalah perbuatan hukum yang dilakukan oleh satu perseroan atau lebih untuk menggabungkan diri dengan perseroan lain yang telah ada dan selanjutnya perseroan yang menggabungkan diri menjadi bubar.

\section{Akuisisi \\ Peraturan Pemerintah Republik Indonesia No. 27 tahun 1998 tentang penggabungan, Peleburan dan Pengambilalihan Perseroan Terbatas, menyatakan bahwa}


akuisisi adalah perbuatan hukum yang dilakukan oleh badan hokum atau orang perseorangan untuk mengambil alih baik seluruh maupun sebagian besar saham perseroan yang dapat mengakibatkan bealihnya pengendalian terhadap perseroan tersebut. Sedangkan berdasarkan PSAK No. 22, akuisisi adalah suatu penggabungan usaha dimana salah satu perusahaan yaitu mengakuisisi (acquirer) memperoleh kendali atas aktiva neto dan operasi perusahaan yang diakuisisi (acquiree), dengan memberikan aktiva tertentu, mengakui suatu kewajiban atau mengeluarkan saham.

\section{Konsolidasi}

Konsolidasi atau peleburan merupakan bentuk khusus merger dimana dua atau lebih perusahaan bersama-sama meleburkan diri dan membentuk perusahaan. Peraturan Pemerintah Republik Indonesia No. 27 tahun 1998 tentang penggabungan, Peleburan dan Pengambilalihan Perseroan Terbatas, menggunakan istilah peleburan untuk istilah konsolidasi dan mendefinisikannya sebagai berikut: "Peleburan adalah perbuatan hukum yang dilakukan oleh dua perseroan atau lebih untuk meleburkan diri dengan cara membentuk satu perseroan baru dan masing-masing perseroan yang meleburkan diri menjadi bubar".

\section{Laporan keuangan}

Laporan keuangan menurut IAI (2009) merupakan bagian dari proses pelaporan keuangan, laporan yang lengkap biasa meliputi neraca, laporan laba/rugi, laporan perubahan posisi perusahaan/perubahan modal, catatan dan laporan lain serta materi penjelasan yang merupakan bagian integral dari laporan keuangan.

Menurut Taswan (2003;37), laporan keuangan merupakan bentuk pertanggungjawaban manajemen terhadap pihak-pihak yang berkepentingan dengan kinerja bank yang dicapai selama periode tertentu. Oleh karena itu, laporan keuangan bank harus memenuhi syarat mutu, dan karakteristik kualitatif seperti yang disampaikan dalam pembahasan kerangka konseptual akuntansi perbankan. Dengan demikian, pihak-pihak pengguna laporan keuangan dapat menggunakannya tanpa dihinggapi keraguan, sementara bagi manajemen bank bahwa laporan keuangan yang telah disusun dapat digunakan sebagai pedoman dalam penyelenggaraan akuntansi.

Sedangkan menurut PSAK Syariah No. 101 komponen laporan keuangan yang lengkap terdiri dari:
a. Laporan Posisi Keuangan
b. Laporan Laba Rugi Komprehensif
c. Laporan Perubahan Ekuitas
d. Laporan Arus Kas
e. Laporan Sumber dan Penyaluran Dana Zakat
f. Laporan Sumber dan Penyaluran Dana Kebajikan
g. Catatan Atas Laporan Keuangan
h. Laporan Posisi Keuangan Awal (dalam hal penyajian kembali atau reklasifikasi)

Laporan keuangan konsolidasi umumnya diterima dalam praktek sebagai cara akuntansi untuk kombinasi bisnis secara internasional. Laporan konsolidasi menjadi relevan bukan hanya terhadap pemakai luar tapi digunakan manajemen untuk kontrol dan koordinasi.

\section{Kinerja Bank}

Kasmir (2000: 273) menjelaskan bahwa kinerja bank merupakan ukuran keberhasilan bagi direksi bank tersebut sehingga apabila kinerja ini buruk bukan tidak mungkin para direksi ini akan diganti. Sedangkan menurut Y. Sri Susilo, dkk. (1999: 22), Kinerja suatu bank dapat diartikan sebagai kemampuan suatu bank untuk melakukan 
kegiatan operasional perbankan secara normal dan mampu memenuhi semua kewajiban dengan baik dengan cara-cara yang sesuai dengan peraturan perbankan yang berlaku. Menurut Sri Susilo, dkk. (1999: 22) kinerja suatu bank merupakan bagian dari kesehatan bank untuk melaksanakan seluruh kegiatan usaha perbankan.

Salah satu alat untuk mengukur kinerja suatu bank dengan menggunakan analisis CAMEL. Unsur-unsur penilaian kinerja dalam analisis CAMEL adalah sebagai berikut (Kasmir (2000: 274):

a. Capital (permodalan)

Penilaian didasarkan kepada permodalan yang dimiliki oleh suatu bank. Salah satu penilaiannya adalah dengan menggunakah metode CAR (capital adequacy rasio), yaitu dengan cara membandingkan modal terhadap Aktiva Tertimbang Menurut Risiko (ATMR).

b. Asset (kualitas aset)

Penilaian didasarkan kepada kualitas aktiva yang dimiliki bank. Rasio yang diukur ada dua macam, yaitu:

1) Rasio aktiva produktif yang diklasifikasikan terhadap aktiva produktif.

2) Rasio penyisihan penghapusan aktiva produktif terhadap aktiva produktif yang diklasifikasikan.

c. Manajemen

Penilaian didasarkan pada manajemen permodalan, manajemen aktiva, manajemen rentabilitas, manajemen likuiditas dan manjemen umum.

d. Earning (Rentabilitas)

Penilaian didasarkan pada rentabilitas suatu bank yang dilihat dari kemampuan dalam menciptakan laba. Penilaian dalam unsur ini didasrakan pada dua macam, yaitu:

1) Rasio laba terhadap total aset (Return on Asset)

2) Rasio beban operasional terhadap pendapatan operasional (BOPO)

e. Liquidity (Likuiditas)

Penilaian likuiditas didasarkan kepada dua macam rasio, yaitu:

1) Rasio jumlah kewajiban bersih call money terhadap aktiva lancar.

2) Rasio antara kredit yang diberikan terhadap dana yang diperoleh bank.

\section{Pemisahan Perusahaan (Spin Off)}

Dalam Pasal 1 Undang-Undang No. 21 Tahun 2008 tentang Perbankan Syariah disebutkan pengertian pemisahan, yaitu pemisahan usaha dari satu Bank menjadi dua badan usaha atau lebih, sesuai dengan ketentuan peraturan perundang-undangan.

Istilah spin off dalam Undang - Undang No. 40 Tahun 2007 tentang Perseroan Terbatas (UUPT) terdapat dalam penjelasan Pasal 135 Ayat (1) huruf b yaitu yang dimaksud dengan "pemisahan tidak murni" lazim disebut spin off. Pemisahan tidak murni (spin off) mengakibatkan sebagian aktiva dan pasiva perseroan beralih karena hukum kepada 1 (satu) perseroan lain atau lebih yang menerima peralihan, dan perseroan yang melakukan pemisahan tersebut tetap ada.

Sedangkan dalam perspektif Undang-Undang No. 13 tahun 2003 tentang ketenagakerjaan Pasal 163, spin off (pemisahan tidak murni) termasuk juga split off (pemecahan/pemisahan murni adalah bentuk perubahan status perusahaan yang dapat menjadi salah satu alasan pemutusan hubungan kerja. Demikian juga, apabila terjadi spin off, maka otomatis terjadi perubahan pemberi kerja (employer) sehingga bagi pekerja new company secara hukum terjadi perubahan hubungan kerja dari existing corporation ke new company. Selain itu, kemungkinan juga terjadi perubahan syarat-syarat kerja, hak dan kewajiban atau tata tertib perusahaan.

Menurut Heriyakto S Hartomo, Direktur Batasa Tazkia Consulting, Pemisahan UUS menjadi BUS yang direncanakan oleh Bank Indonesia (BI) bisa meningkatkan laju industri 
keuangan syariah. Dalam jangka pendek, BUS atau bank baru itu akan mengalami persoalan likuditas. Hal tersebut terjadi karena BUS harus menyediakan dana infrastruktur untuk penyiapan gedung kantor, SDM, dan teknologi informasi, dan dalam jangka panjang, BUS baru dituntut memiliki produktivitas yang agresif. Pasalnya, di tahun pertama BUS memerlukan konsolidasi dan pelatihan SDM yang memerlukan cukup banyak waktu. Sementara di tahun kedua, BUS baru melakukan take off (lepas landas), Kemudian di tahun ketiga, kemungkinan BUS baru bisa bergerak lancar karena produknya lebih banyak.

\section{Hipotesis}

Adapun hipotesis dari penelitian ini adalah sebagai berikut:

a. Komparasi Kinerja BNI Syariah sebelum dan sesudah spin off

Ho : CAR, NPF, NPM, ROA, ROE, dan FDR BNI Syariah sebelum spin off tidak berbeda signifikan dengan sesudah spin off.

Ha : CAR, NPF, NPM, ROA, ROE, dan FDR BNI Syariah sebelum spin off berbeda signifikan dibandingkan sesudah spin off.

b. Komparasi Kinerja BNI Syariah dan BJB Syariah sesudah spin off

Ho : CAR, NPF, NPM, ROA, ROE, dan FDR BNI Syariah sesudah spin off tidak berbeda signifikan dengan BJB Syariah sesudah spin off.

Ha : CAR, NPF, NPM, ROA, ROE, dan FDR BNI Syariah sesudah spin off BNI Syariah sesudah spin off berbeda signifikan dengan BJB Syariah sesudah spin off.

\section{METODE PENELITIAN}

Penelitian ini merupakan kausal komparatif untuk menganalisa kinerja BNI Syariah sesudah spin off. Teknik pengumpulan data dalam penelitian ini menggunakan data sekunder time series berupa laporan keuangan per triwulan yang telah dipublikasikan oleh BNI Syariah selama tahun 2007 sampai dengan tahun 2012 dan laporan keuangan per triwulan yang telah dipublikasikan oleh BJB Syariah selama tahun 2010 sampai dengan tahun 2012 dan terdaftar di direktori Bank Indonesia.

Data yang digunakan adalah data kinerja BNI Syariah dan BJB Syariah yang berupa rasio keuangan dengan berdasarkan laporan keuangan yang telah dipublikasikan setiap triwulan. Objek penelitian yang pertama adalah laporan keuangan BNI Syariah per triwulan dari tahun 2007 hingga tahun 2012 atau periode 3 tahun sebelum spin off (20072009) dan 3 tahun sesudah spin off (2010-2012), yaitu:

a. Laporan Keuangan BNI Syariah Triwulan III, dan IV Tahun 2007

b. Laporan Keuangan BNI Syariah Triwulan I, II, III, dan IV Tahun 2008

c. Laporan Keuangan BNI Syariah Triwulan I, II, III, dan IV Tahun 2009

d. Laporan Keuangan BNI Syariah Triwulan I, II, III, dan IV Tahun 2010

e. Laporan Keuangan BNI Syariah Triwulan I, II, III, dan IV Tahun 2011

f. Laporan Keuangan BNI Syariah Triwulan I, II, III, dan IV Tahun 2012

Objek penelitian yang kedua adalah laporan keuangan BNI Syariah dan BJB Syariah per triwulan dari tahun 2010 hingga tahun 2012. Laporan keuangan tahun 2010 hingga tahun 2012 merupakan laporan keuangan periode 3 tahun sesudah BNI Syariah dan BJB Syariah spin off dari induknya, yaitu:

Laporan Keuangan BNI Syariah dan BJB Syariah Triwulan II, III, dan IV Tahun 2010,2011DAN 2012

Metode analisis data yang digunakan adalah Uji paired sample t-test dan Uji independen sample t-test. Uji paired sample t-test adalah merupakan prosedur yang digunakan untuk membandingkan rata-rata dua variabel dalam satu group. Artinya pula analisis ini berguna untuk melakukan pengujian terhadap dua sampel yang berhubungan atau dua sampel berpasangan. Uji paired sample t-test pada penelitian ini digunakan untuk membuktikan hipotesis yang telah dirumuskan yaitu dengan membandingkan CAR, NPF, 
NPM, ROA, ROE, dan FDR BNI Syariah sebelum dengan sesudah spin off, apakah berbeda signifikan. Data yang digunakan adalah data kinerja BNI Syariah sebelum spin off (tahun 2007 sampai dengan tahun 2009 dengan data per triwulan) dan data kinerja BNI Syariah setelah spin off (tahun 2010 sampai dengan tahun 2012 dengan data per triwulan).

Uji independen sample t-test digunakan untuk membuktikan hipotesis yang telah dirumuskan yaitu dengan membandingkan CAR, NPF, NPM, ROA, ROE, dan FDR BNI Syariah sesudah spin off dengan BJB Syariah sesudah spin off, apakah berbeda signifikan. Prosedur pengujian hipotesis dilakukan dengan menggunakan prosedur uji selisih rata-rata dimana:

- $\alpha=0,05$

- Daerah kritis: Ho ditolak jika sig. $<\alpha$

\section{HASIL DAN PEMBAHSAN}

\section{Kinerja BNI Syariah Sebelum dan Sesudah Spin Off}

Data kinerja BNI Syariah sebelum dan sesudah spin off (tahun 2007 sampai dengan tahun 2012 per triwulan) terlebih dahulu dilakukan uji kenormalan dengan KolmogorovSmirnov untuk menentukan data berdistribusi normal atau tidak. Hasil uji kenormalan dengan Kolmogorov-Smirnov dan transformasi data dapat dilihat pada tabel di bawah ini:

Tabel 1. Hasil Uji Kolmogorov-Smirnov Data Variabel BNI Syariah Sebelum dan Sesudah Spin Off

\begin{tabular}{|c|c|c|c|c|c|}
\hline \multirow{3}{*}{ Rasio } & \multicolumn{5}{|c|}{ Kolmogorov-Smirnov $^{\mathrm{a}}$} \\
\hline & \multicolumn{3}{|c|}{ Uji-1 } & \multicolumn{2}{|c|}{ Uji-2 } \\
\hline & $\mathrm{N}$ & Statistic & Sig. & Statistic & Sig. \\
\hline CAR Sebelum Spin Off & 11 & .200 & .200 & - & - \\
\hline CAR Sesudah Spin Off & 11 & 139. & .200 & - & - \\
\hline NPF Sebelum Spin Off & 11 & .197 & .200 & - & - \\
\hline NPF Sesudah Spin Off & 11 & .143 & .200 & - & - \\
\hline NPM Sebelum Spin Off & 11 & .324 & .200 & - & - \\
\hline NPM Sesudah Spin Off & 11 & .234 & .002 & .322 & .002 \\
\hline ROA Sebelum Spin Off & 11 & .289 & .092 & - & - \\
\hline ROA Sesudah Spin Off & 11 & .363 & .000 & .192 & .200 \\
\hline ROE Sebelum Spin Off & 11 & .202 & .200 & - & - \\
\hline ROE Sesudah Spin Off & 11 & .365 & .000 & .297 & .007 \\
\hline FDR Sebelum Spin Off & 11 & .271 & .023 & .204 & .200 \\
\hline FDR Sesudah Spin Off & 11 & .412 & .000 & .323 & .002 \\
\hline
\end{tabular}

Sumber: Data diolah, 2013

Berdasarkan Tabel 1 di atas, diperoleh simpulan bahwa dari hasil uji kenormalan dengan Kolmogorov-Smirnov, data variabel yang tidak berdistribusi normal adalah NPM, ROA, ROE sesudah spin off serta FDR sebelum dan sesudah spin off karena nilai signifikansinya kurang dari o,05. Oleh karena itu, untuk memperoleh data berdistribusi normal, maka kelima data yang tidak berdistribusi normal tersebut dilakukan pengujian yang kedua melalui manipulasi data dengan mentransformasi data variabel NPM, ROA, ROE sesudah spin off serta FDR sebelum dan sesudah spin off. Hasil dari uji normalitas yang kedua, masih ada 3 data variabel yang tidak berdistribusi normal yaitu NPM, ROE, dan FDR sesudah spin off karena nilai signifikansinya masih di bawah 5 persen. 
Setelah dilakukan uji kenormalan, kemudian dilakukan uji t untuk data variabel CAR, NPF, NPM, ROA, ROE, FDR dengan menggunakan metode analisa paired sample t test dan hasilnya dapat dilihat pada Tabel 2 di bawah ini:

Tabel 2. Hasil Uji Paired Sample t-test BNI Syariah Sebelum dan Sesudah Spin Off

\begin{tabular}{|c|c|c|c|c|}
\hline Rasio & $\begin{array}{c}\text { Mean } \\
\text { Sebelum Spin Off } \\
(\%)\end{array}$ & $\begin{array}{c}\text { Mean } \\
\text { Sesudah } \\
\text { Spin Off } \\
(\%)\end{array}$ & $\mathrm{N}$ & $\begin{array}{c}\text { Sig. } \\
(2 \text {-tail })\end{array}$ \\
\hline CAR & 17,1582 & 22,0764 & 11 & 0.116 \\
\hline NPF & 2,5936 & 2,0145 & 11 & 0.264 \\
\hline NPM & 6,2482 & 7,8336 & 11 & 0.011 \\
\hline ROA & 1,0745 & 0,1418 & 11 & 0.530 \\
\hline ROE & 10,8600 & 1,0818 & 11 & 0.270 \\
\hline FDR & 80,0109 & 86,2664 & 11 & 0.317 \\
\hline
\end{tabular}

Sumber: Data Diolah, 2013.

Berdasarkan Tabel 2 di atas, terlihat bahwa angka probabilitas untuk variabel CAR, NPF, ROA, ROE dan FDR BNI Syariah sebelum dan sesudah spin off adalah lebih besar dari o,05, maka Ho diterima dan Ha ditolak, maka CAR, NPF, ROA, ROE dan FDR BNI Syariah sebelum spin off tidak berbeda signifikan dengan sesudah spin off. Sedangkan angka probabilitas untuk variabel NPM BNI Syariah sebelum dan sesudah spin off di bawah o,05 artinya NPM BNI Syariah sebelum spin off berbeda signifikan dengan sesudah spin off. Berdasarkan hasil pengujian statistik tersebut, secara umum dapat dikatakan bahwa kinerja BNI Syariah sebelum spin off tidak berbeda signifikan dengan kinerja BNI Syariah sesudah spin off.

\section{CAR BNI Syariah Sebelum dan Sesudah Spin Off}

Nilai signifikansi CAR BNI Syariah sebelum dan sesudah spin off adalah sebesar o,116 $(\alpha>0,05)$ artinya bahwa CAR BNI Syariah sebelum spin off tidak berbeda signifikan dibandingkan CAR BNI Syariah sesudah spin off. Hal tersebut terlihat dari nilai rata-rata CAR sebelum spin off adalah sebesar $17 \%$ dan sesudah spin off adalah sebesar $22 \%$, maka dapat diartikan bahwa nilai rata-rata CAR BNI Syariah sesudah spin off hanya berbeda $5 \%$ lebih besar dibandingkan CAR BNI Syariah sebelum spin off.

Kondisi tersebut dikarenakan sesudah spin off BNI syariah mendapat suntikan dana sebesar 1 triliun, sehingga akan berdampak kepada peningkatan nilai CAR. Seharusnya dengan adanya suntikan dana tersebut CAR BNI Syariah bisa lebih baik, namun CAR BNI Syariah sebelum dan sesudah spin off tidak berbeda signifikan. Hal ini disebabkan suntikan dana tersebut digunakan untuk modal kerja dan investasi pengembangan organisasi, sumber daya manusia, dan teknologi informasi dalam rangka pengembangan usahanya. Disamping itu, Bank Indonesia memberikan ketentuan kepada perbankan memiliki CAR minimal sebesar $8 \%$ yang menyebabkan bank selalu menjaga agar CAR yang dimiliki sesuai dengan ketentuan.

\section{NPF BNI Syariah Sebelum dan Sesudah Spin Off}

Nilai signifikansi NPF BNI Syariah sebelum dan sesudah spin off adalah sebesar 0,264 $(\alpha>0,05)$ artinya bahwa NPF BNI Syariah sebelum spin off tidak berbeda signifikan dibandingkan sesudah spin off. Hal ini terlihat dari angka rata-rata NPF sebelum spin off adalah sebesar $2,59 \%$ dan sesudah spin off adalah sebesar 2,01\%, maka dapat diartikan 
bahwa rata-rata NPF BNI Syariah sesudah spin off lebih baik 0,58\% dibandingkan NPF BNI Syariah sebelum spin off atau kualitas aktiva produktif BNI Syariah setelah spin off lebih baik dibandingkan dengan sebelum spin off.

Kondisi tersebut dapat disebabkan yaitu: pertama, BNI Syariah setelah spin off mendapat suntikan dana sebesar $\mathrm{Rp} 1$ triliun yang sebagian dialokasikan kepada pembiayaan; kedua, BNI Syariah setelah spin off semakin baik dari aspek pengawasan, sehingga berdampak kepada kualitas pembiayaan lebih baik (NPF sesudah spin off < NPF sebelum spin off). Namun dikarenakan tambahan modal yang diterima BNI Syariag sesudah spin off lebih banyak digunakan sebagai modal kerja dan investasi dalam rangka pengembangan usahanya dibandingkan untuk penyaluran pembiayaan, maka NPF BNI Syariah sebelum dan sesudah spin off tidak berbeda signifikan.

\section{NPM BNI Syariah Sebelum dan Sesudah Spin Off}

Nilai signifikansi NPM BNI Syariah sebelum dan sesudah spin off adalah sebesar o,o11 $(\alpha<0,05)$ artinya NPM BNI Syariah sebelum spin off berbeda signifikan dibandingkan NPM BNI Syariah sesudah spin off. Nilai rata-rata NPM sebelum spin off adalah sebesar $6,25 \%$ dan sesudah spin off adalah sebesar 7,83\%, maka dapat diartikan bahwa kualitas manajemen BNI Syariah setelah spin off yang diukur dari kemampuannya memperoleh margin lebih baik sebesar 1,58\% dibandingkan sebelum spin off.

Hal tersebut di atas terjadi dikarenakan manajemen BNI Syariah sesudah spin off relatif lebih fokus mengelola bisnisnya, lebih independen, fleksibel serta lebih responsif dan agresif, sehingga manajemen BNI Syariah sesudah spin off bisa menyalurkan pembiayaan lebih baik yang berdampak kepada peningkatan pendapatan margin, namun pencapaian keuntungan (margin) tersebut masih belum maksimal atau tidak sesuai dengan yang diharapkan karena kemungkinan aktiva produkrif yang dimiliki tidak semuanya dalam bentuk pembiayaan (sektor riil) tetapi masih banyak yang ditempatkan dalam bentuk surat berharga dimana tingkat bagi hasil yang akan diperoleh bni Syariah relatif lebih kecil dibannding dengan penempatan dalam bentuk pembiayaan.

\section{ROA BNI Syariah Sebelum dan Sesudah Spin Off}

Nilai signifikansi ROA BNI Syariah sebelum dan sesudah spin off adalah sebesar o,53 $(\alpha>0,05)$ artinya bahwa ROA BNI Syariah sebelum spin off tidak berbeda signifikan dengan ROA BNI Syariah sesudah spin off. Nilai rata-rata ROA sebelum spin off adalah sebesar $1,07 \%$ dan sesudah spin off adalah sebesar $0,14 \%$, artinya bahwa rata-rata tingkat profitabilitas BNI Syariah yang dihasilkan dari pengelolaan aset sebelum spin off tidak berbeda atau lebih rendah o,93\% dibandingkan sesudah spin off.

Kondisi tersebut dapat disebabkan karena sesudah spin off, manajemen BNI Syariah lebih selektif dalam mengelola seluruh aktiva perusahaan untuk menghasilkan laba sehingga dalam pencapaian laba dari total aktiva yang dimiliki masih belum optimal atau tidak sesuai dengan yang diharapkan karena kemungkinan jumlah aktiva tetapnya (fixed asset) terlalu besar sehingga beban depresiasinya juga besar dan pada akhirnya akan menggerus laba perusahaan.

\section{ROE BNI Syariah Sebelum dan Sesudah Spin Off}

Nilai signifikansi ROE BNI Syariah sebelum dan sesudah spin off adalah sebesar o,27 $(\alpha>0,05)$ artinya ROE BNI Syariah sebelum spin off tidak berbeda signifikan dibandingkan ROE BNI Syariah sesudah spin off. Nilai rata-rata ROE BNI Syariah sebelum spin off adalah sebesar 10,86\% dan sesudah spin off adalah sebesar 1,08\%. Hal tersebut dapat diartikan bahwa tingkat profibilitas BNI Syariah yang berasal dari ekuitas sebelum spin off secara rata-rata tidak berbeda atau menurun $9,78 \%$ dibandingkan dengan sesudah spin off. 
Kondisi tersebut di atas disebabkan karena setelah spin off, manajemen BNI Syariah belum dapat mengendalikan biaya-biaya yang diakibatkan karena kegiatan spin off seperti investasi pengembangan organisasi, sumber daya manusia, dan teknologi informasi. Biayabiaya tersebut berdampak pada penurunan tingkat profitabilitas perusahaan. Selain itu, sesudah spin off, BNI Syariah juga mendapat tambahan modal sebesar Rp 1 triliun yang secara langsung menambah jumlah equity BNI Syariah, namun equity tersebut belum dapat dikelola secara maksimal untuk perolehan laba atau dampak perolehan labanya belum dapat dirasakan dalam jangka pendek karena digunakan untuk investasi jangka panjang.

\section{FDR BNI Syariah Sebelum dan Sesudah Spin Off}

Nilai signifikansi FDR BNI Syariah sebelum dan sesudah spin off adalah sebesar 0,317 $(\alpha>0,05)$ artinya FDR BNI Syariah sebelum spin off tidak berbeda signifikan dibandingkan FDR BNI Syariah sesudah spin off. Nilai rata-rata FDR sebelum spin off adalah sebesar $80,01 \%$ dan sesudah spin off adalah sebesar $86,27 \%$. Hal ini berarti bahwa rata-rata tingkat likuiditas BNI Syariah sebelum spin off hanya berbeda lebih besar 6,26\% dibandingkan sesudah spin off.

Kondisi tersebut di atas dapat disebabkan karena setelah spin off, BNI Syariah dalam menyalurkan pembiayaan lebih banyak menggunakan dana modalnya atau belum mengoptimalkan pengelolaan dana pihak ketiga yang dimilikinya. Apabila melihat pada Peraturan Bank Indonesia No. 12/198PBI/2010 tentang Giro Wajib Minimum Bank Umum pada Bank Indonesia dalam Rupiah dan Valuta Asing, yaitu batas bawah FDR adalah sebesar $78 \%$ dan batas atas adalah sebesar $100 \%$, maka rata-rata FDR BNI Syariah sebelum dan sesudah spin off berada diambang batas aman.

\section{Kinerja BNI Syariah Sesudah Spin Off Dibandingkan Dengan Kinerja BJB Syariah Sesudah Spin Off}

Data kinerja BNI Syariah dan BJB Syariah sesudah spin off dari Triwulan II Tahun 2010 sampai dengan Triwulan IV Tahun 2012 terlebih dahulu dilakukan uji kenormalan dengan Kolmogorov-Smirnov untuk menentukan data berdistribusi normal atau tidak. Hasil uji kenormalan dengan Kolmogorov-Smirnov dan transformasi data dapat dilihat pada tabel di bawah ini:

Tabel 3. Hasil Uji Kolmogorov-Smirnov Data Variabel BNI Syariah dan BJB Syariah Sesudah Spin Off

\begin{tabular}{|c|c|c|c|c|c|}
\hline \multirow{3}{*}{ Rasio } & \multicolumn{5}{|c|}{ Kolmogorov-Smirnov $^{\mathrm{a}}$} \\
\hline & \multicolumn{3}{|c|}{ Uji-1 } & \multicolumn{2}{|c|}{ Uji-2 } \\
\hline & $\mathrm{N}$ & Statistic & Sig. & Statistic & Sig. \\
\hline CAR & 22 & 0.115 & .200 & - & - \\
\hline NPF & 22 & 0.139 & .200 & - & - \\
\hline NPM & 22 & 0.193 & .032 & .336 & .000 \\
\hline ROA & 22 & 0.294 & .000 & .319 & .000 \\
\hline ROE & 22 & 0.335 & .000 & .296 & .000 \\
\hline FDR & 22 & 0.223 & .006 & .151 & .200 \\
\hline
\end{tabular}

Sumber: Data Diolah, 2013

Berdasarkan Tabel 3 di atas, diketahui bahwa dari hasil uji kenormalan dengan Kolmogorov-Smirnov hanya data variabel rasio CAR dan NPF yang berdistribusi normal 
karena nilai signifikansinya lebih besar dari o,05. Sedangkan untuk data variabel NPM, ROA, ROE, dan FDR tidak berdistribusi normal karena nilai signifikansinya kurang dari o,05. Oleh karena itu, keempat data variabel tersebut dilakukan pengujian kedua melalui manipulasi data dengan mentransformasi data variabel NPM, ROA, ROE, serta FDR dan menghasilkan hanya FDR yang signifikansinya menjadi di atas o,05, sedangkan NPM, ROA, dan ROE nilai signifikansinya masih di bawah o,05 sehingga data untuk ketiga variabel tersebut tidak berdistribusi normal.

Setelah dilakukan uji kenormalan, kemudian dilakukan uji t dua sample untuk data variabel CAR, NPF, NPM, ROA, ROE, FDR BNI Syariah dan BJB Syariah sesudah spin off dengan menggunakan Independent Sample Test, diperoleh hasil sebagai berikut:

Tabel 4. Hasil Uji Independent Sample Test

BNI Syariah dan BJB Syariah Sesudah Spin Off

\begin{tabular}{|c|c|c|c|c|c|c|}
\hline \multirow[t]{2}{*}{ Rasio } & \multicolumn{2}{|c|}{$\begin{array}{c}\text { Equality of } \\
\text { Variance (Sig.) }\end{array}$} & \multirow[t]{2}{*}{$\mathrm{N}$} & \multirow{2}{*}{$\begin{array}{c}\text { Mean } \\
\text { BNI Syariah } \\
(\%)\end{array}$} & \multirow{2}{*}{$\begin{array}{c}\text { Mean } \\
\text { BJB Syariah } \\
(\%)\end{array}$} & \multirow{2}{*}{$\begin{array}{c}\text { Sig. } \\
\text { (2-tailed) }\end{array}$} \\
\hline & $\mathrm{F}$ & Sig. & & & & \\
\hline CAR & 0,137 & .715 & 11 & 22,0764 & 31,3509 & .003 \\
\hline NPF & 6,049 & .023 & 11 & 5 & 36 & .111 \\
\hline NPM & 0,232 & .635 & 11 & 7,8336 & 7,5436 & .731 \\
\hline ROA & 2,453 & 133 & 11 & 0,1418 & 0,7536 & .643 \\
\hline ROE & 3,858 & .064 & 11 & 1,0818 & 1,7609 & .920 \\
\hline FDR & 0,657 & .427 & 11 & 86,2700 & 106,9218 & .03 \\
\hline
\end{tabular}

Sumber: Data Diolah, 2013.

Berdasarkan Tabel 4 di atas, terlihat bahwa nilai signifikansi dari hasil uji kesamaan varian (homogenitas) dengan $\mathrm{F}$ test (Levene,s Test), data variabel CAR, NPM, ROA, ROE, dan FDR lebih besar dari o,05 artinya bahwa Uji t menggunakan equal variances assumed (diasumsikan varian sama), sedangkan untuk data variabel NPF menggunakan data Uji $t$ equal variances not assumed (diasumsikan varian tidak sama) karena nilai signifikansinya di bawah 0,05.

Berdasarkan hasil Uji t, nilai signifikansi untuk variabel NPF, NPM, ROA, dan ROE adalah di atas 0,05 $(\alpha>0,05)$ artinya bahwa NPF, NPM, ROA, dan ROE BNI Syariah sesudah spin off tidak berbeda signifikan dengan BJB Syariah sesudah spin off. Sedangkan nilai signifikansi CAR dan FDR di bawah o,05 $(\alpha<0,05)$ artinya bahwa ada perbedaan signifikan antara rata-rata CAR dan FDR BNI Syariah sesudah spin off dengan rata-rata CAR dan FDR BJB Syariah sesudah spin off. Sehubungan dengan hasil pengolahan data tersebut, maka secara umum dapat diartikan bahwa kinerja BNI Syariah sesudah spin off tidak berbeda signifikan dengan kinerja BJB Syariah sesudah spin off.

\section{CAR BNI Syariah dan BJB Syariah Sesudah Spin Off}

Nilai signifikansi CAR BNI Syariah dan BJB Syariah sesudah spin off dengan equal variance assumed adalah o,003 $(\alpha<0,05)$ artinya bahwa rata-rata CAR BNI Syariah sesudah spin off berbeda siginifikan dengan rata-rata CAR BJB Syariah sesudah spin off. Nilai ratarata CAR BNI Syariah sesudah spin off sebesar 22,08\% dan BJB Syariah adalah sebesar 31,35\%. Artinya bahwa aspek permodalan BJB Syariah setelah spin off lebih tinggi 9,27\% dibandingkan dengan BNI Syariah. Namun hal tersebut bukan berarti BJB Syariah lebih baik dari BNI Syariah, kemungkinan BJB Syariah tidak menggulirkan modalnya ke sektor riil sehinggga terjadi idle. Namun aspek permodalan kedua bank tersebut cukup aman karena ketentuan CAR dari Bank Indonesia adalah minimal sebesar 8\% dan dengan ketentuan 
tersebut mengakibatkan bank-bank selalu berusaha menjaga agar CAR yang dimiliki sesuai dengan ketentuan.

\section{NPF BNI Syariah dan BJB Syariah Sesudah Spin Off}

Nilai signifikansi NPF dengan equal variance not assumed adalah o,111 atau lebih besar dari $0,05(\alpha>0,05)$, artinya bahwa rata-rata NPF BNI Syariah sesudah spin off tidak berbeda siginifikan dengan rata-rata NPF BJB Syariah sesudah spin off. Nilai rata-rata NPF BNI Syariah sesudah spin off adalah sebesar 2,01\% dan BJB Syariah sebesar 1,3\%. Rata-rata kualitas aktiva produktif BJB Syariah sesudah spin off lebih baik $0,71 \%$ dibandingkan dengan BNI Syariah.

Kondisi tersebut di atas disebabkan karena yaitu: pertama, setelah spin off BNI syariah dan BJB Syariah mendapat tambahan dana untuk menambah modal kerja dan sebagian modalnya dialokasikan kepada pembiayaan; kedua, setelah spin off, baik BNI syariah maupun BJB Syariah semakin baik aspek pengawasannya. Kedua hal tersebut dapat membuat kualitas pembiayaan lebih bagus sehingga rasio NPF turun. Rata-rata rasio NPF setelah spin off, baik BNI Syariah (2,015\%) maupun BJB Syariah $(1,3 \%)$ masih diambang batas aman yaitu maksimum sebesar 5 persen.

\section{NPM BNI Syariah dan BJB Syariah Sesudah Spin Off}

Nilai signifikansi NPM dengan equal variance assumed adalah o,731 atau lebih besar $(\alpha>0,05)$ artinya bahwa rata-rata NPM BNI Syariah sesudah spin off tidak berbeda siginifikan dengan rata-rata NPM BJB Syariah sesudah spin off dengan perbedaan rata-rata (mean diference) hanya sebesar $0,29 \%$. Nilai rata-rata NPM BNI Syariah sesudah spin off adalah sebesar 7,83\% dan untuk BJB Syariah sebesar 7,54\%. Berdasarkan angka tersebut, dapat diartikan bahwa kualitas manajemen BNI Syariah sesudah spin off yang diukur berdasarkan kemampuannya memperoleh margin lebih baik sebesar $0,29 \%$ dibandingkan dengan BJB Syariah.

Kondisi tersebut terjadi karena manajemen BNI Syariah dan BJB Syariah setelah spin off lebih fokus mengelola bisnisnya, lebih independen, fleksibel serta lebih responsif dan agresif, sehingga BNI Syariah dan BJB Syariah dapat menyalurkan pembiayaan lebih baik yang berdampak kepada peningkatan pendapatan margin.

\section{ROA BNI Syariah dan BJB Syariah Sesudah Spin Off}

Nilai signifikansi ROA sesudah spin off dengan equal variance assumed adalah o,643 atau di atas $0,05(\alpha>0,05)$, artinya bahwa rata-rata ROA BNI Syariah sesudah spin off tidak berbeda signifikan dengan rata-rata ROA BJB Syariah. Perbedaannya hanya sebesar o,61\%. Nilai rata-rata ROA BNI Syariah sesudah spin off adalah sebesar $0,14 \%$ dan BJB Syariah adalah sebesar $0,75 \%$. Artinya bahwa tingkat perolehan laba atau profitabilitas BJB Syariah sesudah spin off yang berasal dari hasil pengelolaan asset lebih baik sebesar o,61\% dibandingkan dengan BNI Syariah.

Sepertinya halnya dengan perolehan rasio NPM, BNI Syariah dan BJB Syariah setelah spin off lebih fokus, independen, fleksibel, responsif, dan agresif dalam mengelola bisnisnya, termasuk dalam menyalurkan pembiayaannya sehingga berdampak kepada peningkatan pendapatan margin.

\section{ROE BNI Syariah dan BJB Syariah Sesudah Spin Off}

Nilai Signifikansi ROE sesudah spin off dengan equal variance assumed adalah 0,92 atau di atas $0,05(\alpha>0,05)$, artinya bahwa rata-rata ROE BNI Syariah sesudah spin off tidak berbeda signifikan dengan rata-rata ROE BJB Syariah. Perbedaannya adalah sebesar o,68\%. Nilai rata-rata ROE BNI Syariah sesudah spin off adalah sebesar 1,08\% dan BJB Syariah $1,76 \%$. Hal ini dapat diartikan bahwa tingkat perolehan laba atau profitabilitas BJB Syariah 
sesudah spin off yang berasal dari pengelolaan modal atau ekuitas lebih tinggi sebesar o,68\% dibandingkan BNI Syariah.

Kondisi tersebut terjadi karena setelah spin off, BNI Syariah dan BJB Syariah masih belum bisa mengendalikan biaya-biaya yang ditimbulkan dari kegiatan setelah spin off seperti investasi pengembangan organisasi, sumber daya manusia, dan teknologi informasi yang berdampak kepada melambatnya peningkatan profitabilitas perusahaan karena keuntungan atau manfaat dari investasi jangka panjang belum dapat dirasakan secara langsung pada awal-awal tahun setelah investasi. Selain itu, kurangnya optimalisasi penggunaan modal juga berdampak kepada penurunan nilai rasio ROE.

\section{FDR BNI Syariah dan BJB Syariah Sesudah Spin Off}

Nilai signifikansi FDR sesudah spin off dengan equal variance assumed adalah o,31 atau di atas $0,05(\alpha>0,05)$, artinya bahwa rata-rata FDR BNI Syariah sesudah spin off tidak berbeda signifikan dengan rata-rata FDR BJB Syariah. Nilai rata-rata FDR BNI Syariah sesudah spin off adalah sebesar 86,27\% dan BJB Syariah sebesar 106,92\%. Artinya bahwa tingkat likuiditas BNI Syariah sesudah spin off lebih baik sebesar 20,66\% dibandingkan BJB Syariah. Kondisi tersebut juga dapat diartikan bahwa BJB Syariah lebih ekspansif dalam mengelola dana pihak ketiganya melalui pembiayaan dibandingkan BNI Syariah.

Apabila melihat pada Peraturan Bank Indonesia No. 12/198PBI/2010 tentang Giro Wajib Minimum Bank Umum pada Bank Indonesia dalam Rupiah dan Valuta Asing, yaitu batas bawah FDR adalah sebesar $78 \%$ dan batas atas adalah sebesar $100 \%$, maka rata-rata FDR BNI Syariah berada dalam ambang batas ketentuan BI yaitu sebesar 86,27\%. Sedangkan rata-rata FDR BJB Syariah berada di atas ambang batas atas ketentuan BI yaitu sebesar 106,92\%. Hal ini berarti BJB Syariah dalam menyalurkan pembiayaannya melebihi jumlah dana pihak ketiga yang diterimanya dan menggunakan dana modal yang dimilikinya.

\section{SIMPULAN}

Kinerja BNI Syariah sebelum spin off tidak berbeda signifikan dengan kinerja BNI Syariah sesudah spin off. Hal tersebut dibuktikan dengan nilai signifikansi untuk variabel CAR, NPF, ROA, ROE dan FDR di atas 0,05 $(\alpha>0,05)$ dan hanya variabel NPM yang nilai signifikansinya di bawah $0,05(\alpha<0,05)$ dengan perbedaan nilai rata-rata NPM hanya sebesar $1,58 \%$. Kondisi tersebut dikarenakan setelah spin off, BNI Syariah mendapat tambahan modal sebesar Rp 1 triliun yang digunakan untuk investasi jangka panjang seperti pengembangan organisasi, sumber daya manusia, dan teknologi informasi sehingga keuntungan/manfaatnya yang berdampak kepada profitabilitas belum dapat dirasakan dalam jangka pendek. Selain itu, BNI Syariah belum dapat mengendalikan biaya-biaya yang diakibatkan karena kegiatan spin off sehingga tingkat profitabilitas perusahaan setelah spin off menurun. Namun, sesudah spin off, BNI Syariah lebih berani dalam menyalurkan dana pihak ketiga melalui ekspansi pembiayaan dibanding sebelum spin off.

Secara umum, kinerja BNI Syariah sesudah spin off tidak berbeda signifikan dengan kinerja BJB Syariah sesudah spin off. Hal ini terlihat dari nilai signifikansi untuk variabel NPF, NPM, ROA, dan ROE di atas o,05 $(\alpha>0,05)$. Sedangkan untuk rasio CAR dan FDR, ada perbedaan signifikan antara rata-rata CAR dan FDR BNI Syariah sesudah spin off dengan rata-rata CAR dan FDR BJB Syariah karena $\alpha<0$,05. Rasio CAR BNI Syariah sebesar 22,08\% dan BJB Syariah sebesar 31,35\%, artinya dalam aspek permodalan BJB Syariah lebih tinggi 9,27\% dibandingkan dengan BNI Syariah. Sedangkan untuk rasio FDR, nilai rata-rata FDR BNI Syariah sesudah spin off sebesar 86,27\% dan BJB Syariah sebesar 106,92\%. Artinya bahwa tingkat likuiditas BNI Syariah sesudah spin off lebih baik sebesar 20,66\% dibandingkan BJB Syariah. Kondisi tersebut terjadi karena setelah spin off, BNI Syariah dan BJB Syariah masih belum bisa mengendalikan biaya-biaya yang ditimbulkan dari kegiatan 
setelah spin off seperti pengembangan organisasi, sumber daya manusia, dan teknologi informasi sehingga peningkatan profitabilitas perusahaan melambat karena keuntungan atau manfaat dari investasi tersebut belum dapat dirasakan secara langsung pada awal-awal tahun.

\section{PUSTAKA ACUAN}

Harahap, Sofyan S, dkk. 2005. Akuntansi Perbankan Syariah. Jakarta: LPFE-Usakti.

Karim, Adiwarman. 2003. Bank Islam Analisa Fiqih dan Keuangan. Jakarta: The International Institute For Islamic Thought (IIT).

Kasmir. 2008. Manajemen Perbankan. Jakarta: Rajawali Pers.

Moin, Abadul. 2004. Merger, Akuisisi, E Divestasi. Yogyakarta: Ekonesia.

Pedoman Akuntansi Perbankan Syariah Indonesia (PAPSI). 2003. Jakarta: Ikatan Akuntan Indonesia.

Silalahi, Ulber. 2010. Metode Penelitian Sosial. Bandung: PT Refika Aditama.

Susilo, Y. Sri, dkk. 1999. Bank E Lembaga Keuangan Lain. Jakarta: Salemba Empat.

Taswan. 2003. Akuntansi Perbankan. Semarang: UPP AMP YKPN.

Tadoro, Michael P. 2000. Pembangunan Ekonomi. Jakarta: Bumi Aksara.

I.A. 2011. Peta Bisnis Perbankan Syariah. Sharing, 59, hal. 10.

\section{Internet}

.......Bank Jabar Banten Syariah akan Buka Kantor Cabang di Jakarta, dari Era Muslim web: http://ib2.eramuslim.com/2010/o8/o4/bank-jabar-banten-syariah-akan-bukakantor-cabang-di-jakarta/, diunduh 31 Januari 2013.

BJB Syariah akan Tambah Modal 300 Miliar, dari Antara Jawa Barat Web: http://www.antarajawabarat.com/lihat/cetak/32622, diunduh 31 Januari 2013.

Status Serikat Pekerja pada Perusahaan Spin Off, dari Hukum Online Web: http://www.hukumonline.com/klinik/detail/lt4d 4of61d2cf2o/status-serikat-pekerjapada-perusahaan-spin-off, diunduh 10 Januari 2013.

Admin. 2011. Spin off Unit Usaha Syariah menjadi Bank Umum Syariah, dari LPPI Web: http://www.lppi.or.id/index.php/module/Blog/sub/1/id/, diunduh 13 Desember 2012.

Afrizal. 2009. Sebuah Analisis Tentang Spin Off, dari http://www. afickafrizal.blogspot.com/2009/o1/sebuah-analisis-tentang-spin-off.html, diunduh 13 Desember 2012.

Bank Indonesia. 2011. Kebijakan dan Perkembangan Perbankan Syariah di Indonesia, dari http://www.bi.go.id/web/id/Perbankan/Perbankan+Syariah/, diunduh 20 Maret 2012.

Direktorat Perbankan Syariah, Bank Indonesia. 2011. Outlook Perbankan Syariah Indonesia Tahun 2012, hal.1, dari http://www.bi.go.id/NR/rdonlyres/BAo429EA-EF4E-4ADBB32A-E6A83B1C4505/25052/outlook_perbankan_syariah_2012.pdf, diunduh 30 Maret 2012.

Karim. 2008. Saat Tepat Pemisahan Bank Syariah, dari Media Indonesia Web: http; shariaeconomu.blogspot, diunduh 13 Desember 2012.

Rizqullah. 2010. BNI Syariah Resmi Menjadi Bank Umum Syariah, dari SWA web: http://swa.co.id, diunduh 13 Desember 2012.

Siregar, Mulya. E. 2001. Solusi Permasalah Perbankan Nasional, dari Republika Online Web, diunduh 30 Maret 2012.

\section{Peraturan}


Undang-Undang Republik Indonesia No. 7 Tahun 1992 tentang Perbankan.

Undang-Undang Republik Indonesia No. 1o Tahun 1998 tentang Perubahan atas UndangUndang Republik Indonesia No. 7 Tahun 1992 tentang Perbankan.

Undang-Undang Republik Indonesia No. 21 Tahun 2008 tentang Perbankan Syariah.

Peraturan Pemerintah Republik Indonesia No. 27 Tahun 1998 tentang Penggabungan, Peleburan dan Pengambilalihan Perseroan Terbatas.

Peraturan Bank Indonesia No. 5/10/PBI/2003 Tanggal 11 Juni 2003 tentang Prinsip Kehatihatian Dalam Kegiatan Penyertaan Modal.

Peraturan Bank Indonesia No. 11/10/PBI/2009 Tanggal 19 Maret 2009 tentang Unit Usaha Syariah.

Peraturan Bank Indonesia No. 13/1/PBI/2011 Tanggal 5 Januari 2011 tentang Penilaian Tingkat Kesehatan Bank Umum.

Peraturan Bank Indonesia No. 12/21/PBI/2010 Tanggal 19 Oktober 2010 tentang Rencana Bisnis Bank.

Pernyataan Standar Akuntansi Keuangan (PSAK) No. 1 tentang Penyajian Laporan Keuangan.

Pernyataan Standar Akuntansi Keuangan (PSAK) No. 4 tentang Laporan Keuangan Konsolidasi.

Pernyataan Standar Akuntansi Keuangan (PSAK) No. 22 tentang Kombinasi Bisnis.

Pernyataan Standar Akuntansi Keuangan (PSAK) No. 31 tentang Akuntansi Perbankan.

Pernyataan Standar Akuntansi Keuangan (PSAK) No. 101 tentang Penyajian Laporan Keuangan Syariah.

Pernyataan Standar Akuntansi Keuangan (PSAK) No. 102 tentang Akuntansi Murabahah.

Pernyataan Standar Akuntansi Keuangan (PSAK) No. 105 tentang Akuntansi Mudharabah.

Pernyataan Standar Akuntansi Keuangan (PSAK) No. 106 tentang Akuntansi Musyarakah. 